Article

\title{
Assessment of Socio-Environmental Vulnerability Due to Tropical Cyclones in La Paz, Baja California Sur, Mexico
}

\author{
Elvia Aida Marín-Monroy ${ }^{1, *}$, Víctor Hernández Trejo ${ }^{2}$, Miguel Angel Ojeda Ruiz de la Pena ${ }^{1}$, \\ Gerzain Avilés Polanco ${ }^{3}$ and Nuñez León Barbara ${ }^{2}$ \\ 1 Department of Fisheries, Universidad Autónoma de Baja California Sur, La Paz 23080, Mexico; \\ maojeda@uabcs.mx \\ 2 Department of Economics, Universidad Autónoma de Baja California Sur, La Paz 23080, Mexico; \\ victorh@uabcs.mx (V.H.T.); bnunez_13@alu.uabcs.mx (N.L.B.) \\ 3 Cátedra CONACYT-Centro de Investigaciones Biológicas del Noroeste, La Paz 23096, Mexico; \\ gpolanco@cibnor.mx \\ * Correspondence: emarin@uabcs.mx
}

Received: 18 November 2019; Accepted: 1 January 2020; Published: 20 February 2020

\begin{abstract}
Climate change will increase the likelihood of adverse events such as droughts, forest fires, and intensification of tropical cyclones, which are known to cause flooding (IPCC, 2014). The effects of these events are a cause of concern for both authorities and citizens, so they prioritize actions that reduce adverse impacts, especially in cities with higher risk. Therefore, the objective of this work was to measure the degree of socio-environmental vulnerability of households to identify the risk areas in the city of La Paz, Baja California Sur, one of the regions with a high degree of incidence of hurricanes in the northwest of Mexico. For this, surveys were carried out with heads of households in 251 homes, and information was aggregated to calculate the vulnerability index through principal components analysis (PCA), which were stratified by the Dalenius-Hodges method, the degree of vulnerability was classified into three categories by the Opiyo method, considering three strata of the Likert scale, 1 = highly vulnerable, $2=$ moderately vulnerable, $3=$ less vulnerable. The results showed that households that are in the highly vulnerable category are $33 \%$ within a range of the index -3.77243 to -0.939141 . Moderately vulnerable households constitute $36 \%$ with values from -0.929141 to 0.956385 . While the least vulnerable represent $31 \%$ of households with an index range of 0.966385 to 5.6952 . The results have revealed the levels of high and moderate socio-environmental vulnerability by tropical cyclones of $69 \%$ homes in La Paz. The above allowed to generate risk maps that will be taken into account in planning and civil protection over adverse events.
\end{abstract}

Keywords: risk index; vulnerable population; tropical cyclones; maps; Mexico northwest

\section{Introduction}

The effects of climate change have become one of the main concerns of citizens and authorities globally. According to the report of the Intergovernmental Panel on Climate Change (IPCC), global climate change will increase the likelihood of adverse events, including heat waves, droughts, forest fires, intensification, and increased tropical cyclone frequency, as well as heavy rainfall that could cause flooding and landslides [1].

These events can affect the population in multiple dimensions, vulnerability to natural disasters caused by adverse weather events has spatial, environmental, social, economic, and cultural dimensions. The IPCC defines vulnerability as "the degree to which a system is susceptible and unable to cope with the adverse effects of climate change, including climate variability and adverse events". It also 
depends on the differences between susceptibility, which includes exposure and sensitivity, and on the other hand, the ability to cope with or recover from the damage caused, which is known as resilience.

One of the vulnerabilities due to heavy rainfall related to cyclones and rainfall is the large number of people in urban areas exposed to episodes of flooding, especially in informal settlements. It is estimated that about 600 million people by the year 2100 will be prone to hurricane impacts [2] and it is considered that the greatest effects of climate change will occur in coastal areas, as the average sea level will have increased by $38 \mathrm{~cm}$ from 1990 to 2080, the number of people susceptible to flooding in low-lying areas will increase five times [3].

The destructive potential of tropical cyclones (TC) has increased markedly since the 1970s. According to Emanuel Kerry [4], the power dissipation of TC is highly correlated with the sea surface temperature, muti-decadal oscillations and global warming. The risk and exposure to natural disasters will be significantly increased if we consider the increase in the population that lives in coastal areas and the increase in the destructive potential of the TCs in both the North Pacific Ocean and the North Atlantic. In the case of Mexico, during the last three decades, both exposure factors and vulnerability factors have increased in the face of adverse hydrometeorological events, during the $90 \mathrm{~s}, 90 \%$ of people who lost their lives due to natural phenomena, were due to storms, floods, and droughts, mainly due to settlements in highly vulnerable areas [5,6].

According to Akter and Mallick [7], vulnerability and resilience are the basis of the new natural disaster risk management paradigm. However, empirical evidence on socio-economic resilience and its relation to poverty and vulnerability are still limited. The authors of a study in Bangladesh found that TC have negative impacts on the population, mainly on income, employment, access to clean water and sanitary services. They also found that the poorest households are more vulnerable and suffer significantly more damage compared to higher-income households. The causes are usually multidimensional, but it is important to develop strategies to reduce the risks associated with the stress and uncertainty caused by the climate in the population and particularly the risks associated with floods and torrential rains $[8,9]$.

On the other hand, Park, et al. [10] conducted a study in South Korea where they analyzed the consequences of the impacts of TC during 1970-2010. Their results suggest that the increase in the level of income per capita has helped to reduce vulnerability. They also argued that the results on the topic of prevention of hydrometeorological disasters were partly due to unintended adaptation factors, such as construction regulations, industrial structures, and land uses. There is even evidence that other types of variables, such as population size and the type of construction used, also influence exposure to impacts [11,12]. Recently the importance of the idea of sustainable buildings encompasses various issues regarding the optimization of energy, water, land, and material conservation $[13,14]$.

The study of vulnerability at a disaggregated or micro level is a requirement for planning at the local level as well as prioritizing resilient strategies in communities [15]. One of the areas with the greatest urgency to carry out these activities is the arid and semi-arid regions because they are at the highest risk [16], such is the case in northwestern Mexico.

Since Baja California Sur is the federative entity with the highest risk due to the impact of TC in Mexico [17] and because the IPCC scenarios warn that climate change will increase the frequency of its formation, this research has a theoretical basis in the pressure and release (PAR) model with the objective of identifying the relationship of the factors that determine natural disasters due to the impact of TC. The pressure and release model can be seen in Figure 1.

In Baja California Sur, TC impact at least once a year during the months of May to November and the most frequent effects in the cities are: Flooding, landslides, strong winds, storm surge, and lack of communication due to flooding of streams.

Conclusive to the above, the objective of this study was to measure the degree of socio-environmental vulnerability of households to identify risk areas in the city of La Paz, Baja California Sur, one of the cities in Northwestern Mexico with the highest degree of incidence of adverse climatic events. 


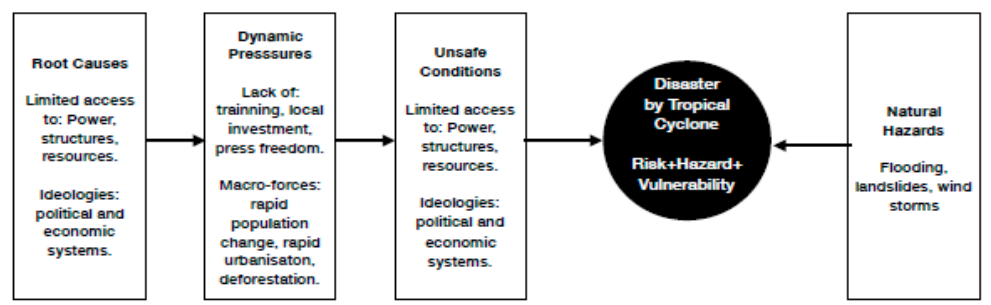

Figure 1. Pressure and release model. Source: Adaptation from Blake et al. (1994). At risk: Natural hazards, people's vulnerability, and disasters.

\section{Methods}

\subsection{Study Area}

The municipality of La Paz is located in the State of Baja California Sur $\left(24^{\circ} 08^{\prime} 32^{\prime \prime} \mathrm{N} 110^{\circ} 8^{\prime} 39^{\prime \prime} \mathrm{W}\right)$ and has an area of 20,275 $\mathrm{km}^{2}$. According to the National Institute of Geography and Statistics (INEGI by its Spanish acronym) [18], the city has a population of 272,711 inhabitants. According to the State Plan of Action against Climate Change (IPCC), La Paz is one of the main municipalities with the greatest vulnerability to TC, because their homes have a greater probability of impact each year (48\%) at a greater risk, according to NOAA data that recorded 125 TC in the Northeast Pacific with direct impact in Mexico. It has even been detected that this municipality is the one that most frequently receives the impact of category 1 hurricanes (according to the scale Saffir-Simpson) with a return period of 5.6 years [17].

\subsection{Methods}

Assessing climate change vulnerability is a widely complex challenge and has become a multidisciplinary task since it affects several areas of activities and resources [19-21]. There have been several recent studies that aimed to assess the effects of climate change on coastal cities by using different approaches [22-26]. Moreover, there have been many studies to assess the perception and vulnerability due to hurricane impacts and effects [27-30]. Since there are several methods and approaches to evaluate vulnerability, the Dalenius-Hodges and Opiyo methods [31] were adopted for this research, due to their easy application, estimation, and interpretation. Moreover, it is an integrated assessment approach that combines socio-economic and biophysical factors, commonly used in the analysis of regionally-based vulnerability $[9,32]$.

With the objective of obtaining information to estimate the vulnerability index, a survey was applied where the sampling unit was the dwelling, and in this one, household heads of households in the municipality of La Paz were interviewed. Data were obtained from 251 private homes, which exceeds the representative sample for population size, the date of application was September 2017. The survey included four sections: (1) Demographic and economic characteristics of the household, (2) physical conditions and services which provides for housing, (3) level of severity of damage caused by Hurricane Odile and (4) level of social capital of households related to education and culture for disaster prevention by TCs. The Likert scale from 1 to 5 was used in ascending order. The first part of the survey refers to the physical conditions of the home. The questions considered in the questionnaire, which make up the items of the socio-environmental dimensions are shown in Appendix A.

To generate the socio-environmental vulnerability index due to the impact of TCs, the regression method was used in order to obtain the matrix of standardized coefficients, the standardized values of each variable and the sample in the corresponding equation of each factor were substituted. The scores obtained correspond to the vulnerability indices of each dimension: (1) Exposure, (2) adaptive capacity, (3) sensitivity. To obtain the general vulnerability index, the formula developed by the IPCC was applied, which is the following:

$$
\text { Vulnerability }=(\text { Adaptative capacity })-(\text { Sensitivity-Exposure })
$$


If the adaptive capacity exceeds sensitivity and exposure, the home will be less vulnerable to impacts from tropical cyclones, and if the capacity is lower it means that the home is more vulnerable.

The degree of vulnerability was classified into three categories by the method of Opiyo et al. [31], the least vulnerable households are those in a situation where they can cope with impacts of a tropical category 1 cyclone on the Saffir-Simpson scale, moderately vulnerable households are those that require temporary assistance in case of stress or shock, while the highly vulnerable are those which, even with immediate assistance, are not able to resume the level of well-being prior to a tropical cyclone impact.

Once the socio-environmental vulnerability index for TC in La Paz was obtained, the degree of vulnerability was classified by means of the Dalenius-Hodges stratification technique [33], which consists in the formation of strata privileging that the previous variance of each stratum is minimum and maximum between each of them, forming homogeneous strata.

For the construction of a vulnerability index the model is as follows:

$$
V_{1}=\left(A_{1} X_{1}+A_{2} X_{2}+\cdots+A_{n} X_{n j}\right)-\left(A_{n}+1 Y_{1 j}+A_{n}+2 Y_{2 j}+\cdots+A_{n}+\mathrm{n} Y_{n j}\right)
$$

where $V_{1}$ is the vulnerability index, the $Y_{\mathrm{s}}$ and $X \mathrm{~s}$ are the sensitivity and exposure values, the $A \mathrm{~s}$ correspond to the coefficient matrix values obtained by the principal component analysis (PCA). The use of the PCA technique has allowed the construction of composite indicators that measure different levels of social vulnerability of the population against threats due to adverse hydro-meteorological events and have been validated in international and local studies [34,35]. It is important to mention that this work is based on an implementation of vulnerability methods that used PCA to derive this phenomenon according to the IPCC recommendations. Three layers of the Likert scale were considered, 1 = highly vulnerable, 2 = moderately vulnerable, 3 = less vulnerable.

Adaptive capacity is the effects of facing climate change or some situations, which helps to reduce impacts or to anticipate them. Adaptive capacity is the ability of a system to adjust to climate change, including variability and adverse climate effects, to moderate potential damage, seize opportunities and deal with the consequences [36].

Exposure is identified by changes in climatic conditions, either by an increase or decrease in adverse events. The exhibition is the presence of people, livelihoods, species or ecosystems, environmental functions, services and resources, infrastructure, or economic, social or cultural assets in places and environments that could be negatively affected [1]. This indicator was considered taking into account the following factors: Frequency of adverse events, modeled changes in the climate, and environmental problems.

The ten components or variables that were analyzed to calculate the index were the following: (1) Type of roofing and housing construction material, (2) type of housing floor construction material, (3) perception of the degree of damage caused by flood, (4) perception of the degree of damage caused by flooding, (5) perception of the degree of damage caused by high winds, (6) perception of the degree of damage caused by storm surge, (7) perception of the degree of damage caused by floods of streams, (8) degree of information on risks and housing, (9) type of risk reported, (10) means of information for monitoring civil protection bulletins.

\section{Results}

\subsection{Descriptive Statistics: Analysis of Demographic Aspects and Damage Perception}

The results of the survey on demographic characteristics and physical conditions of the household, showed the following aspects in their descriptive statistics: $69.7 \%$ of the heads of households were born in the entity. Regarding the type of material with which the house was built, we found that $79.3 \%$ had a roof of concrete material, $15.5 \%$ had sheets of cardboard, metal, asbestos, or fiber cement, $3.6 \%$ had a wooden roof, and $0.4 \%$ had tiles. While $1.2 \%$ of private homes had a roof of waste materials. With regard to the material with which the walls of the houses were built, we found that $13.9 \%$ had 
reed, palm, cardboard, asbestos, or metal walls. These indicators are part of the variables related to exposure.

The previous data show us that one in every five homes was built with weak materials, and therefore, they were in a degree of exposure that potentiates the probability of occurrence of a natural disaster due to the possible impact of winds or floods.

The analysis of the perception of the degree of damage caused by flooding was carried out through the question: How would you rate the degree of damage caused to your home due to flooding in your street, block, or neighborhood? It was found that $3.2 \%$ of the surveyed homes were highly vulnerable to floods, $14.4 \%$ were moderately vulnerable, and $82.4 \%$ were little vulnerable to flooding in their homes. Households that are highly vulnerable to flooding could cause the loss of material assets, increase the risk of disease, require a financial burden for the replacement of lost material assets and repairs to their homes.

In the case of landslides, the perception is that $94.2 \%$ of households are little or not vulnerable to this type of affectations. However, in the case of damage caused by high winds, the percentage of homes with very serious and serious damage reaches up to $47.4 \%$. High winds affect homes due to their strength, and can cause the total loss of home and material goods, by lifting, by tilting or tipping over. In the street or block, the effects are falling poles and trees.

Figure 2 shows the georeferenced surveys applied in the municipality of La Paz in inhabited private homes, and the risks map with areas susceptible to flooding by risk level: Low, medium, high, and very high.

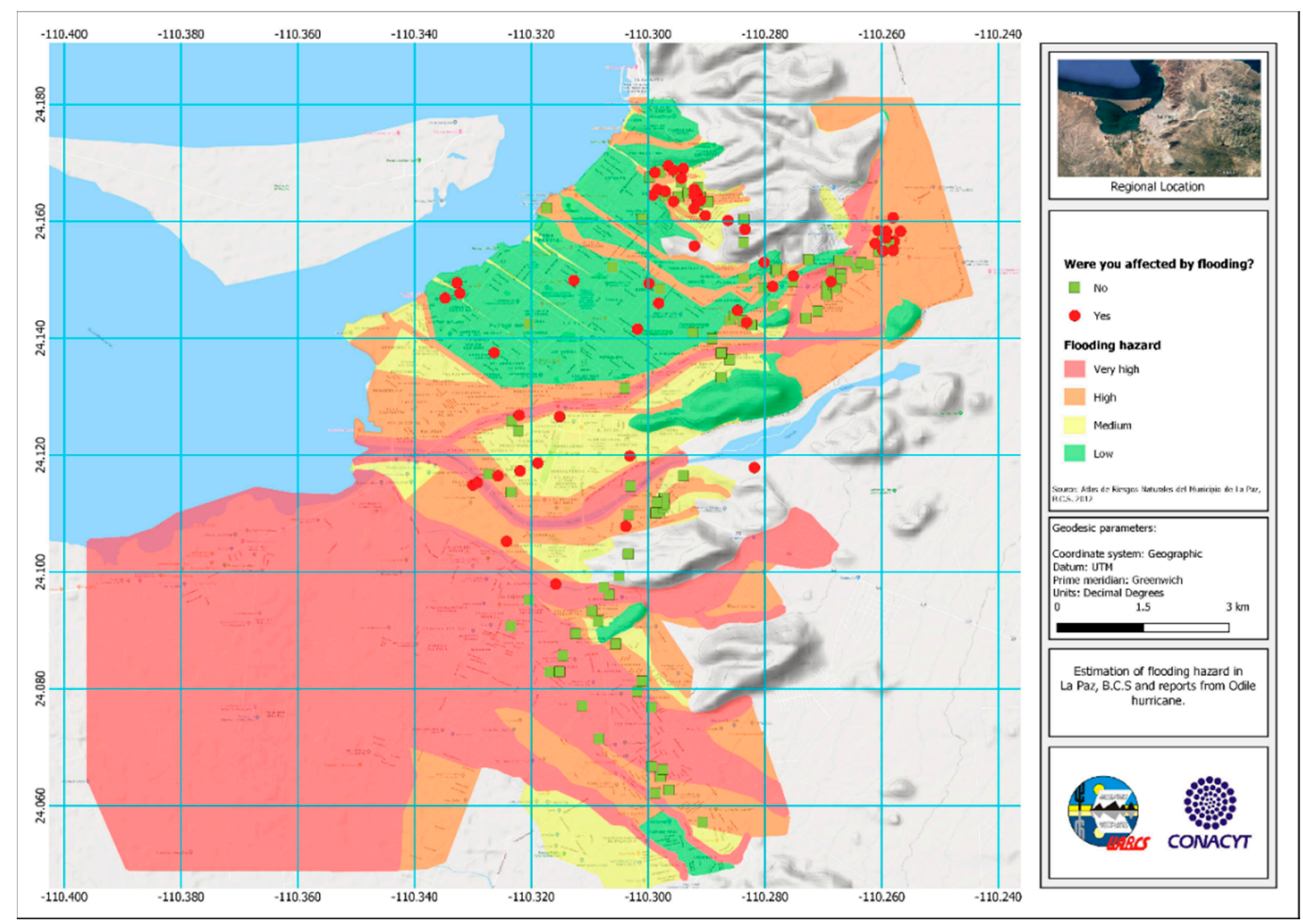

Figure 2. Georeferenced surveys applied over the flooding risks map of the municipality of La Paz. Source: Modified by Atlas de Riesgos y Peligros Naturales del Municipio de La Paz, BCS (SEDESOL, 2012).

\subsection{Socio-Environmental Vulnerability Index due to the Impact of Tropical Cyclones}

The analysis of the main components based on the standardization of variables mentioned above, resulted in a Kaiser-Meyer-Olkin value of $7.1(0.713)$ which is considered acceptable for a reduction of data. The analysis showed three factors: 
Factor number 1 explains $27.92 \%$ of the total variance, in which it explains the exposure of households, through the perception of damage caused during Hurricane Odile.

Factor number 2 explains $23.09 \%$ of the total variance, in which it explains adaptive capacity, this information is through social capital, education, and culture for the prevention of natural disasters caused by climate change.

Factor number 3 explains $14.51 \%$ of the total variance, in which it explains the sensitivity of households to quality conditions in household construction materials.

The total variance explained by the three factors is $65.53 \%$, as shown in the following Table 1 .

Table 1. Explained variance by component.

\begin{tabular}{|c|c|c|c|c|c|c|c|c|c|}
\hline \multirow{3}{*}{ Component } & \multirow{2}{*}{\multicolumn{3}{|c|}{ Eigen Values }} & \multirow{2}{*}{\multicolumn{3}{|c|}{$\begin{array}{c}\text { Initial Solution. } \\
\text { Loads Square Sum }\end{array}$}} & \multirow{2}{*}{\multicolumn{3}{|c|}{$\begin{array}{c}\text { Rotate Solution. } \\
\text { Loads Square Sum }\end{array}$}} \\
\hline & & & & & & & & & \\
\hline & Total & $\%$ of Variance & $\%$ Cumulative & Total & $\%$ of Variance & $\%$ Cumulative & Total & $\%$ of Variance & $\%$ Cumulative \\
\hline 1 & 2.792 & 27.924 & 27.924 & 2.792 & 27.924 & 27.924 & 2.715 & 21.152 & 27.152 \\
\hline 2 & 2.39 & 23.09 & 51.014 & 2.39 & 23.09 & 51.014 & 2.037 & 23.066 & 50.218 \\
\hline 3 & 1.452 & 14.518 & 65.532 & 1.452 & 14.518 & 65.532 & 1.531 & 15.315 & 65.532 \\
\hline 4 & 0.909 & 9.087 & 74.62 & & & & & & \\
\hline 5 & 0.635 & 6.349 & 80.968 & & & & & & \\
\hline 6 & 0.56 & 5.601 & 86.569 & & & & & & \\
\hline 7 & 0.437 & 4.37 & 90.94 & & & & & & \\
\hline 8 & 0.379 & 3.786 & 94.725 & & & & & & \\
\hline 9 & 0.289 & 2.892 & 97.617 & & & & & & \\
\hline 10 & 0.238 & 2.383 & 100 & & & & & & \\
\hline
\end{tabular}

Method: Principal components analysis. Source: Self elaboration.

For the interpretation of the results through the correlation of the variables with respect to the factors by which they are grouped, the Varimax rotation was applied [37]. It was found that the level of severity of damage perceived by flood it is related (0.75) to the tropical cyclone exposure component. Factor one is the perception of the level of damage caused by landslides $(0.84)$, storm tide $(0.83)$, and creek surge (0.82).

Factor 2 is related to adaptive capacity and knowledge about tropical cyclone formation (0.81). Knowing the Saffir-Simpson scale of TC and potential damages associated with each category is related to (0.90) the adaptive capacity of the locality, as well as knowledge about the phases of the Early Warning System of Tropical Cyclones [38] zoom-in (0.89). Factor 3, the physical characteristics of the home, is related to the sensitivity to effects of TC (0.77), (0.56), and (0.72), respectively.

The results show that the majority of households are in the highly vulnerable category, with $33 \%$ within a range of the index -3.77243 to -0.939141 . The moderately vulnerable constitute $36 \%$ with values from -0.929141 to 0.956385 . While the least vulnerable represent $31 \%$ of households with an index range of 0.966385 to 5.6952 . The results reveal levels of high and moderate socio-environmental vulnerability by TC of $69 \%$ in homes in La Paz.

The following Table 2 shows the main findings on socio-environmental vulnerability due to the impact of TC as a category I hurricane on the Saffir-Simpson scale.

Table 2. Rotate components matrix ${ }^{\text {a. }}$

\begin{tabular}{|c|c|c|c|c|}
\hline Num. & Question & 1 & 2 & 3 \\
\hline 1 & What kind of material is most of the roof of your house made of? & 0.165 & -0.091 & 0.769 \\
\hline 2 & What kind of material is most of the floor of your house made of? & -0.143 & -0.033 & 0.56 \\
\hline 3 & What kind of material are the walls of your house made of? & -0.092 & 0.015 & 0.727 \\
\hline 5 & $\begin{array}{l}\text { How would you rank the damage done to your house due to landslides or collapse in your street, block, or } \\
\text { neighborhood? }\end{array}$ & 0.841 & -0.03 & -0.052 \\
\hline 6 & How would you rank the damage done to your house due to storm surge in your street, block, or neighborhood? & 0.836 & 0.044 & -0.173 \\
\hline 7 & How would you rank the damage done to your house due to creek stream flood in your street, block, or neighborhood? & 0.823 & -0.108 & 0.024 \\
\hline 10 & How would you rank your knowledge about the Early Warning System? & 0.006 & 0.895 & 0.035 \\
\hline
\end{tabular}




\section{Discussion}

It is evident that the analysis and determination of vulnerability levels in cities are a priority activity, to lessen the negative impact of adverse events associated with climate change $[9,15]$. In the case of Mexico, some of the priority lines of research for adaptation to climate change are the characterization of vulnerability by type of threat and social sector, and the use of risk mapping and coastal-marine vulnerability [39], which has contributed to the knowledge on this important subject.

The results of this study have generated a useful tool for risk prevention through vulnerability maps. They have been used in cities that actively work on planning under a climate change adaptation approach such as Madrid, in a study where they generated maps for different types of impacts [8]. One of the advantages of this type of space-time vulnerability tool is that it allows the design of territorial and sectoral intervention strategies in strategic risk reduction [35].

Regarding the percentages of vulnerable populations, in general terms, international and national studies have shown a lower vulnerability in their cities. The population of Madrid resulted in lower percentages of the highly vulnerable population, $22.3 \%$ against the $33 \%$ found for La Paz, however, they estimated four levels of vulnerability, due to methodological differences [8]. In the case of national studies, the coastal city of Manzanillo did not show a polarization, because half of its population presented a low vulnerability and $23.5 \%$ a high vulnerability [35]. In the case of Baja California Sur, the city of Loreto showed that $70 \%$ of households were highly vulnerable to hurricane impacts [40].

It is important to note that in the presence of large-scale natural events, public action or civil protection authorities may be in different stages of intervention, either before, during, or after the occurrence, and the approaches to action may be of at least of two types. The first is civil protection or reactive action to safeguard the integrity of the inhabitants, and the second is impact of prevention or proactive action to safeguard the socio-economic functioning of the affected places [41]. The above is relevant because floods and tropical cyclones have contributed little more than $32 \%$ and $30 \%$, respectively, to significant damage to the population, including deaths and people affected, so they occupy the first and second place in causes [42].

The study showed that within the prevention actions and strategies that increase adaptive capacity, it is important to provide timely information to the population about the Saffir-Simpson scale and the potential damages associated with each category, as well as information on the phases of the "Early Warning System" of Civil Protection [40]. The vulnerability of geo-referencing areas is a valuable tool for the prevention of risks associated with hurricanes and tropical cyclones, which are predictable. An important aspect to promote the resilience that must be considered in civil protection systems is the energy sustainability of buildings. This topic will be a new line of research to consider in future studies $[13,14]$.

\section{Conclusions}

Vulnerability levels of La Paz, Baja California Sur, México households were determined using a univariate stratification technique to measure the magnitude of the degree of vulnerability to the impact of category 1 tropical cyclones on the Saffir-Simpson scale. According to the results, it is recommended to include within the urban planning and development system of the city of La Paz the infrastructure and urban equipment necessary to reduce the impacts of TC, as well as to avoid human settlements in flooding or moving areas identified in the risks map.

It seems paramount to strengthen the participation and action of the population at risk, and promote the dissemination of the information generated, risks maps for the impact of TC and, therefore, strengthen early warning systems, as well as prevention actions in case of emergencies due to hydrometeorological phenomena. In order to improve resilience in La Paz, in addition to increasing household knowledge, it is known that improving the conditions of the materials with which housing is built, specifically floors, walls, and ceilings, prevents the impact of the TC that represent a risk to the population. 
We obtained the vulnerability perception of the population and added it to the official flooding risk map, information that will be helpful in validating and providing more accurate information for civil protection in activities of prevention.

For resilience in the cities, it is important to develop more research about the effects of climate change in communities, and because the new plans and developments promote sustainability of buildings and better use of the land use, these studies should take into consideration the TC impacts on energy and water supply, both strategic elements for modern life standards.

Author Contributions: Conceptualization, E.A.M.-M. and G.A.P.; methodology, V.H.T., H.A.P.; software, N.L.B., validation, E.A.M.-M., V.H.T., M.A.O.R.d.l.P. and G.A.P.; formal analysis, E.A.M.-M. and M.A.O.R.d.l.P.; investigation, N.L.B.; resources, G.A.P.; data curation, N.L.B.; writing—original draft preparation, E.A.M.M.; writing-review and editing, M.A.O.R.d.1.P., V.H.T.; visualization, M.A.O.R.d.1.P., G.A.P.; supervision, E.A.M.-M.; project administration, H.A.P., E.A.M.-M.; funding acquisition, H.A.P. All authors have read and agreed to the published version of the manuscript.

Funding: This research was funded by National Council of Science and Technology from Mexico (CONACYT), grant number 288536.

Conflicts of Interest: The authors declare no conflict of interest.

\section{Appendix A Questionnaire to Measure Vulnerability in Households}

\section{Part I. Housing materials.}

1. What material is most of the floor of this house made of?
(1) Earth, (2) Cement,
(3) Mosaic (4)
(4) Ceramics
(5) Wood or marble

2. What material is most of the roof of this house made of?

(1) Waste material, (2) Sheets (cardboard, metal, asbestos, fiber cement) (3) Wood, (4) Tile,

(5) Concrete.

3. What material are most of the walls of this house made of?

(1) Waste material, (2) Bamboo or palm reed, (3) Cardboard, asbestos, metal sheets (4) Wood, adobe or muddy, (5) Partition, brick, block, quarry stone, cement or concrete.

\section{Part II Damage caused by the last hurricane (Odile).}

4. How would you rate the degree of damage caused to your home due to flooding in your street, block, or neighborhood?

Scale $=(1$ No Damage ... 5 High Damage $)$

5. How would you rate the degree of damage caused to your home due to storm surge in your home, street, or block?

6. How would you rate the degree of damage caused to your home or property due to landslides?

7. How would you rate the degree of damage caused to your home because of the increase in streams near your home, street, or block?

\section{Part III Level of knowledge for the prevention of natural disasters.}

8. How would you rate your level of knowledge about the tropical hurricane formation process?

Scale $=(1$ No Knowledge ... . 5 High Knowledge $)$

9. How would you rate your level of knowledge about the phases of the Early Warning System of Tropical Cyclones (SAT-CT 2003) approach-distance?

10. How would you rate your level of knowledge about the Saffir-Simpson hurricane scale and potential wind, precipitation, and storm surge damage? 


\section{References}

1. IPCC. Climate Change 2014: Synthesis Report. Contribution of Working Groups I, II and III to the Fifth Assessment Report of the Intergovernmental Panel on Climate Change; Pachauri, R.K., Meyer, L.A., Eds.; IPCC: Geneva, Switzerland, 2014; p. 151.

2. McGranahan, G. The Rising Tide: Assessing the Risks of Climate Change and Human Settlements in Low Elevation Coastal Zones. Available online: http://journals.sagepub.com/doi/abs/10.1177/0956247807076960 (accessed on 8 October 2019).

3. Klein, R.J.T.; Nicholls, R.J.; Mimura, N. Coastal adaptation to climate change: Can the IPCC Technical Guidelines be applied? Mitig. Adapt. Strateg. Glob. Chang. 1999, 4, 239-252. [CrossRef]

4. Kerry, E. Increasing destructiveness of tropical cyclones over the past 30 years. Nature 2005, 436, 686-688.

5. Magaña, V.O. (Ed.) Los Impactos de El Niño en México; Dirección General de Protección Civil, Secretaría de Gobernación: Ciudad de México, México, 1999.

6. Segob. Programa Nacional de Protección Civil 2001-2006; Sistema Nacional de Protección Civil, Secretaria de Gobernación: Ciudad de México, México, 2001; p. 92.

7. Akter, S.; Mallick, B. The poverty-vulnerability-resilience nexus: Evidence from Bangladesh. Ecol. Econ. 2013, 96, 114-124. [CrossRef]

8. Tapia, C.; Abajo, B.; Feliu, E.; Fernández, J.G.; Pedró, A.; Castaño, J. Análisis DE Vulnerabilidad Ante El Cambio Climático en El Municipio DE Madrid; Ayuntamiento de Madrid: Madrid, Spain, 2015.

9. Madu, I. Spatial vulnerability of rural households to climate change in Nigeria: Implications for internal security. Working Paper No.2. Climate Change ans African Political Stability; CAAPS: Austin, TX, USA, 2012.

10. Park, D.S.R.; Ho, C.H.; Nam, C.C.; Kim, H.S. Evidence of reduced vulnerability to tropical cyclones in the Republic of Korea. Environ. Res. Lett. 2015, 10, 054003. [CrossRef]

11. Romero, E. Ciclones tropicales: Tendencias y potencial de afectación en Baja California Sur. In Baja California Sur ante el Cambio Climático; Vulnerabilidad Adaptación y Mitigación; Universidad Autónoma de Baja California Sur: La Paz, México, 2013; pp. 69-92.

12. Freeman, A.C.; Ashley, W.S. Changes in the US hurricane disaster landscape: The relationship between risk and exposure. Nat. Hazards 2017, 88, 659-682. [CrossRef]

13. Li, Z.X.; Shahsavar, A.; Al-Rashed, A.A.; Kalbasi, R.; Afrand, M.; Talebizadehsardari, P. Multi-objective energy and exergy optimization of different configurations of hybrid earth-air heat exchanger and building integrated photovoltaic/thermal system. Energy Convers. Manag. 2019, 195, 1098-1110. [CrossRef]

14. Sadineni, S.B.; Madala, S.; Boehm, R.F. Passive building energy savings: A review of building envelope components. Renew. Sustain. Energy Rev. 2011, 15, 3617-3631. [CrossRef]

15. Fraser, E.D.G.; Dougill, A.J.; Hubacek, K.; Quinn, C.H.; Sendzimir, J.; Termansen, M. Assessing vulnerability to climate change in dryland livelihood systems: Conceptual challenges and interdisciplinary solutions. Ecol. Soc. 2011, 16, 3. [CrossRef]

16. Notenbaert, A.; Karanja, S.N.; Herrero, M.; Felisberto, M.; Moyo, S. Derivation of a household-level vulnerability index for empirically testing measures of adaptative capacity and vulnerability. Reg. Environ. Chang. 2013, 13, 459. [CrossRef]

17. Romero Vadillo, E.; y Romero Vadillo, I.G. Estimación del riesgo en las viviendas de Baja California Sur ante el impacto de ciclones tropicales. In Teoría y Praxis; Universidad de Quintana Roo: Cozumel, México, 2016; pp. 50-73. Available online: http://www.redalyc.org/articulo.oa?id=456147940004 (accessed on 14 October 2019).

18. Instituto Nacional de Estadística y Geografía. Conteo de Población y Vivienda; Instituto Nacional de Estadística y Geografía: Ciudad de México, México, 2015; Available online: www.inegi.org.mx/app/indicadores/ (accessed on 16 October 2019).

19. McIntosh, R.D.; Becker, A. Expert evaluation of open-data indicators of seaport vulnerability to climate and extreme weather impacts for U.S. North Atlantic ports. Ocean Coast. Manag. 2019, 180, 104911. [CrossRef]

20. Oo, A.T.; Van Huylenbroeck, G.; Speelman, S. Assessment of climate change vulnerability of farm households in Pyapon District, a delta region in Myanmar. Int. J. Disaster Risk Reduct. 2018, 28, 10-21. [CrossRef] 
21. Dzogaac, M.; Simateleab, D.; Mungac, C. Assessment of ecological vulnerability to climate variability on coastal fishing communities: A study of Ungwana Bay and Lower Tana Estuary, Kenya. Ocean Coast. Manag. 2018, 163, 437-444. [CrossRef]

22. AlQahtany, A.M.; Abubakar, I.R. Public perception and attitudes to disaster risks in a coastal metropolis of Saudi Arabia. Int. J. Disaster Risk Reduct. 2020, 44, 101422. [CrossRef]

23. Myers, M.R.; Barnard, P.L.; Beighley, E.; Cayan, D.R.; Dugan, J.E.; Feng, D.; Hubbar, D.M.; Lacobellis, S.F.; Melack, J.M.; Page, H.M. A multidisciplinary coastal vulnerability assessment for local government focused on ecosystems, Santa Barbara area, California. Ocean Coast. Manag. 2019, 182, 104921. [CrossRef]

24. Hoque, M.A.A.; Ahmed, N.; Pradhan, B.; Roy, S. Assessment of coastal vulnerability to multi-hazardous events using geospatial techniques along the eastern coast of Bangladesh. Ocean Coast. Manag. 2019, 181, 104898. [CrossRef]

25. Koroglu, A.; Ranasinghe, R.; Jiménez, J.A.; Dastgheib, A. Comparison of Coastal Vulnerability Index applications for Barcelona Province. Ocean Coast. Manag. 2019, 178, 104799. [CrossRef]

26. Rabby, Y.W.; Hossain, M.D.B.; Hasan, M.U.I. Social vulnerability in the coastal region of Bangladesh: An investigation of social vulnerability index and scalar change effects. Int. J. Disaster Risk Reduct. 2019, 41, 101329. [CrossRef]

27. Pérez-Montero, O.; Milanés-Batista, C. Social perception of coastal risk in the face of hurricanes in the southeastern region of Cuba. Ocean Coast. Manag. 2019. [CrossRef]

28. Vázquez-González, C.; Moreno-Casasola, P.; Peralta-Peláez, L.A.; Monroy, R.; Espejel, I. The value of coastal wetland flood prevention lost to urbanization on the coastal plain of the Gulf of Mexico: An analysis of flood damage by hurricane impacts. Int. J. Disaster Risk Reduct. 2019, 37, 101180. [CrossRef]

29. Hernández, M.L.; Carreño, M.L.; Castillo, L. Methodologies and tools of risk management: Hurricane risk index (HRi). Int. J. Disaster Risk Reduct. 2018, 31, 926-937. [CrossRef]

30. Gibb, C. A critical analysis of vulnerability. Int. J. Disaster Risk Reduct. 2018, 28, 327-334. [CrossRef]

31. Opiyo, F.E.O.; Wasonga, O.R.; Nyangito, M.N. Measuring household vulnerability to climate-induced stresses in pastoral rangeland of Kenya: Implications for resilience programming. Pastor. Res. Policy Pract. 2014, 4, 10. Available online: http://www.pastoralismjournal.com/content/4/1/10 (accessed on 8 September 2019). [CrossRef]

32. Deressa, T.; Hassan, R.M.; Ringler, C. Measuring Ethiopian Farmers' Vulnerability to Climate Change Across Regional States; Discussion Paper 00806; International Food Policy Research Institute: Washington, DC, USA, 2008.

33. Dalenius, T.; Hodges, J. Minimum Variance Stratification. J. Am. Stat. Assoc. 1959, 54, 88-101. [CrossRef]

34. Cutter, S.L.; Finch, C. Temporal and spatial changes in social vulnerability to natural hazards. Proc. Natl. Acad. Sci. USA 2008, 107, 2301-2306. [CrossRef]

35. Bohórquez, J.E.T. Evaluación de la vulnerabilidad social ante amenazas naturales en Manzanillo (Colima) Un aporte de método. Investig. Geográficas Boletín del Inst. de Geogr. UNAM 2013, 81, 79-93. [CrossRef]

36. IPCC. 2001: Climate Change 2001: The Scientific Basis. Contribution of Working Group I to the Third Assessment Report of theIntergovernmental Panel on Climate Change; Houghton, J.T., Ding, Y., Griggs, D.J., Noguer, M., van der Linden, P.J., Dai, X., Maskell, K., Johnson, C.A., Eds.; Cambridge University Press: Cambridge, UK; New York, NY, USA, 2001; p. 881.

37. Kaiser, H.F. The varimax criterion for analytic rotation in factor analysis. Psychometrika 1958, 23, $187-200$. [CrossRef]

38. Sistema de Alarma Temprana para Ciclones Tropicales; Secretaría de Gobernación, Gobierno de México: Ciudad de México, México, 2019. Available online: http://proteccioncivil.gob.mx/work/models/ ProteccionCivil/Resource/62/1/images/siatctnueva.pdf (accessed on 14 October 2019).

39. Landa, R.; Magaña, V.; Neri, C. Agua Y Clima: Elementos Para La Adaptación Al Cambio Climático; Secretaría del Medio Ambiente y Recursos Naturales, Centro de Ciencias Atmosféricas, UNAM: Ciudad de México, México, 2008.

40. Avilés-Polanco, G.; Beltrán-Morales, L.F.; Almendarez-Hernández, M.A. Vulnerabilidad Socio-Ambiental Por Impacto DE Ciclones Tropicales en Un áRea Natural Protegida: Loreto, Baja California Sur, México; UABCS, Universidad Autónoma Chapingo: Ediciones de la Noche, Mexico, 2019. 
41. Constantino, T.; Roberto, M.; Dávila, I.; Hilda, R. Una aproximación a la vulnerabilidad y resiliencia ante eventos hidrometeorológicos extremos en México. Política y Cultura 2011, 36, 15-44.

42. Obasi, G.O.P. Climate Change: Expectation and reality. In Proceedings of the World Renewable Energy Congress VI, Brighton, UK, 1-7 July 2000; pp. 4-9. [CrossRef] 